\title{
IN-VITRO PHAGOCYTOSIS IN PYRIDOXINE DEFICIENCY
}

\author{
O. P. VAN BiJsterveld \\ Laboratory of Microbiology, State University, \\ Catharijnesingel 59, Utrecht, The Netherlands
}

BLEPHARO-CONJUNCTIVITIS ANGULARIS is a surface infection due to a Moraxella, in which phagocytosis might be expected to play an important role in the first line of defence, yet in conjunctival smears from patients with angular conjunctivitis bacteria are seldom seen in the polymorphonuclear leucocytes. Pyridoxine deficiency may be important in this apparently defective cellular response, since phagocytosis is decreased in the pyridoxine-deficient rat (Cottingham and Mills, 1943), and there is medical (Mitsui, Hinokuma and Tanaka, 1951) and experimental (Irinoda and Mikami, 1958) evidence that moraxella infections of the outer eye are related to pyridoxine deficiency.

This study was carried out to reinvestigate the effect of pyridoxine deficiency on the ingestive capacity in vitro of cells of the myeloid series of guinea-pigs, taking into account the effect that differences in the ratio of phagocytes to bacteria may exert on phagocytosis.

\section{MATERIALS AND METHODS}

The ratio of cells to bacteria (c/b) and the cell concentration were kept constant and the experiment was carried out in a single day, since preliminary experiments employing conventional counting techniques showed that no correction factor could compensate for fluctuations caused by variations in cell-to-bacteria ratios, cell concentration, or the biological activity of the phagocytes on different days.

Cell concentration was found to exert a significant effect only when mixtures were chilled after incubation and during centrifugation. In these experiments ingestion during incubation was slow. The maximum proportion of phagocytosing cells was found at $70 \mathrm{~min}$. (95 per cent. confidence limits $30-110 \mathrm{~min}$.) and $100 \mathrm{~min}$. (80-120 min.) for animals on a deficient diet and control animals respectively. When mixtures were centrifuged at room temperature after incubation, ingestion continued in the sediment and the maximum proportion of phagocytosing cells was found at $15 \mathrm{~min}$. (11-19 min.) and $8 \mathrm{~min}$. (2-14 min.) for diet-deficient and control animals respectively.

\section{Experimental design}

Male guinea-pigs weighing $350 \mathrm{~g}$ were used: nine received the normal and nine the pyridoxine-deficient diet. The pyridoxine-deficient diet (Central Institute of Nutrition and Food Research T.N.O. Zeist) contained $0.1-0.2 \mathrm{mg}$ pyridoxine per $\mathrm{kg}$, and $50 \mathrm{mg}$ desoxypyridoxine (DOP) per $\mathrm{kg}$ to suppress the uptake of pyridoxine remaining in the diet or derived from other uncontrollable sources. Toxic effects of DOP on cell vitality and phagocytic activity were checked in final concentrations ranging from 5 to $120 \mu \mathrm{g}$ per ml in the in-vitro systems. After 50 days of dieting, $15 \mathrm{ml}$ of sterile saline was injected into the peritoneal cavity. Eleven hours later, the abdominal cavity was rinsed with $40 \mathrm{ml}$ of Hanks'

Received 11 March 1970; revised version accepted 5 Aug. 1970. 


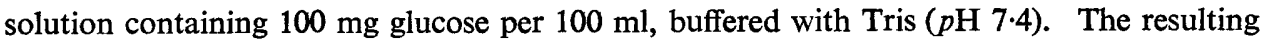
cell suspension was collected in siliconised screw-cap bottles containing heparin in a final concentration of $10 \mathrm{mg}$ per $100 \mathrm{ml}$. The cells were washed three times at $250 \mathrm{~g}$ in HanksTris solution containing bovine albumin (Armour fraction $V$ ) in a final concentration of $100 \mathrm{mg}$ per $100 \mathrm{ml}$.

Four counts were made of each suspension in the Coulter Counter model A at alternate polarities with a tube aperture of $100 \mu \mathrm{m}$ at gain 3, amplification 4 and threshold 43 .

Moraxella nonliquefaciens strain no. 21 was grown overnight in serum meat infusion broth on a turntable inclined at an angle of $45^{\circ}$ rotating at 32 r.p.m. The moraxella suspension was washed three times in Hanks-Tris solution containing bovine albumin. Bacterial counts were made in the Coulter Counter with a tube aperture of $30 \mu \mathrm{m}$ at gain 4 , amplification 7 and threshold 35 . All counts were corrected for background and coincidence.

Blood was obtained by cardiac puncture. Separated serum was added to the in-vitro system in a final concentration of 20 per cent.

Cell suspensions were adjusted to a final concentration of $5 \times 10^{6}$ phagocytes per $\mathrm{ml}$. The cell-to-bacterium ratios were $0.44\left(R_{1}\right)$ and $0.66\left(R_{2}\right)$. Cells, bacteria and homologous serum were placed in sterile, siliconised $5 \mathrm{ml}$ screw-cap bottles and placed on a turntable inclined at $45^{\circ}$, rotating at 6 r.p.m., and incubated for 60 min. at $37^{\circ} \mathrm{C}$.

Addition of bacteria to cell suspensions from animals receiving normal and pyridoxinedeficient diets was randomised.

After incubation, the bottles were centrifuged at $450 \mathrm{~g}$ for $5 \mathrm{~min}$. at room temperature, and two smears of the deposit were stained with May-Grünwald-Giemsa. On each slide 400 cells were examined and the distribution of cell-types, the proportion of phagocytosing cells $(\phi)$ and the average number of ingested bacteria $(\bar{x})$ were determined. Thus 1600 cells were studied from each animal. The origin of the slides was unknown at the time of reading, which was conducted in a standardised manner.

\section{RESULTS}

After 50 days of dieting, two of the animals on the diet, but none of the control animals, had been lost. The average weight increase over the period of the diet-deficient animals was $42 \mathrm{~g}$ (95 per cent. confidence limits 16-67 g) and that of the control animals $203 \mathrm{~g}(182-223 \mathrm{~g})$.

DOP did not depress cell vitality or the ingestive capacity of phagocytes. There was no appreciable difference in the concentration of cells in the peritoneal exudate of pyridoxine-deficient $\left[3.24 \times 10^{6}\{95\right.$ per cent. confidence limits $\left.\left.(1.92-4.56) \times 10^{6}\right\}\right]$ and control animals $\left[3.17 \times 10^{6}\{95\right.$ per cent. confidence limits $\left.(2 \cdot 64-3 \cdot 70) \times 10^{6}\right\}$ ].

The polymorphonuclear leucocytes and metamyelocytes constituted the main body of phagocytes and showed sufficient phagocytic activity for this to be analysed separately. The salient features of the entire experiment are summarised in table I, which shows that the average number of ingested bacteria for the polymorphonuclear leucocytes, metamyelocytes and all cells combined was respectively 40,31 and 27 per cent. higher in the control animals than in the pyridoxine-deficient animals at $R_{1}$. The difference between the groups in the proportion of cells participating in phagocytosis was also higher at $R_{1}$. A significant difference $(\mathrm{P}=0.01)$ was found in the average ratios of polymorphonuclear leucocytes to metamyelocytes between diet and control animals ( 3.6 and 1.5 respectively).

The four parameters used were $(a)$ the average number of ingested bacteria at the two cell-to-bacterium ratios 0.44 and $0.66\left(\bar{x} R_{1}\right.$ and $\left.\bar{x} R_{2}\right)$ and $(b)$ the 
proportion of cells participating in phagocytosis at the two cell-to-bacterium ratios $\left(\phi R_{1}\right.$ and $\left.\phi R_{2}\right)$. These served for comparison of phagocytic activity between pyridoxine-deficient and control animals. The method of analysis

TABLE I

Mean number of ingested bacteria per phagocyte $(\bar{x})$ and proportion of cells participating in phagocytosis $(\phi)$ at cell-to-bacteria ratios of $0.44\left(R_{1}\right)$ and $0.66\left(R_{2}\right)$

\begin{tabular}{|c|c|c|c|c|c|c|c|c|c|c|c|c|c|}
\hline \multirow{4}{*}{$\begin{array}{c}\text { Diet } \\
\text { provided }\end{array}$} & \multirow{4}{*}{$\begin{array}{l}\text { Guinea- } \\
\text { pig no. }\end{array}$} & \multicolumn{12}{|c|}{ Value, for } \\
\hline & & \multicolumn{4}{|c|}{$\begin{array}{l}\text { polymorphonuclear } \\
\text { leucocytes at }\end{array}$} & \multicolumn{4}{|c|}{ metamyelocytes at } & \multicolumn{4}{|c|}{ all phagocytic cells at } \\
\hline & & \multicolumn{2}{|c|}{$R_{1}$, of } & \multicolumn{2}{|c|}{$R_{2}$, of } & \multicolumn{2}{|c|}{$R_{1}$, of } & \multicolumn{2}{|c|}{$R_{2}$, of } & \multicolumn{2}{|c|}{$R_{1}$, of } & \multicolumn{2}{|c|}{$R_{2}$, of } \\
\hline & & $\bar{x}$ & $\phi$ & $\bar{x}$ & $\phi$ & $\vec{x}$ & $\phi$ & $\bar{x}$ & $\phi$ & $\bar{x}$ & $\phi$ & $\bar{x}$ & $\phi$ \\
\hline \multirow[t]{2}{*}{$\begin{array}{c}\text { Pyridoxine- } \\
\text { deficient }\end{array}$} & $\begin{array}{l}1 \\
2 \\
3 \\
4 \\
5 \\
6 \\
7 \\
7 \\
8 \\
9\end{array}$ & $\begin{array}{l}2.00 \\
1.00 \\
1.21 \\
0.93 \\
1.75 \\
1.09 \\
1.01 \\
1.25 \\
0.43\end{array}$ & $\begin{array}{l}0 \cdot 69 \\
0 \cdot 46 \\
0 \cdot 60 \\
0 \cdot 49 \\
0 \cdot 65 \\
0 \cdot 40 \\
0 \cdot 45 \\
0.53 \\
0 \cdot 27\end{array}$ & $\begin{array}{l}1.41 \\
0.55 \\
1 \cdot 11 \\
0.84 \\
1.11 \\
0.94 \\
0.72 \\
0.80 \\
0.20\end{array}$ & $\begin{array}{l}0 \cdot 58 \\
0 \cdot 24 \\
0 \cdot 50 \\
0 \cdot 40 \\
0 \cdot 42 \\
0 \cdot 37 \\
0 \cdot 36 \\
0 \cdot 40 \\
0 \cdot 14\end{array}$ & $\begin{array}{l}0.93 \\
0.53 \\
0.47 \\
0.47 \\
0.58 \\
0.69 \\
0.39 \\
0.61 \\
0.16\end{array}$ & $\begin{array}{l}0.41 \\
0.28 \\
0.27 \\
0.27 \\
0.32 \\
0.33 \\
0.23 \\
0.35 \\
0.14\end{array}$ & $\begin{array}{l}0.97 \\
0.35 \\
0.60 \\
0.27 \\
0.31 \\
0.38 \\
0.14 \\
0.37 \\
0.08\end{array}$ & $\begin{array}{l}0.44 \\
0 \cdot 18 \\
0.30 \\
0 \cdot 16 \\
0 \cdot 20 \\
0.23 \\
0.12 \\
0 \cdot 25 \\
0.07\end{array}$ & $\begin{array}{l}1.62 \\
0.81 \\
1.09 \\
0.86 \\
1.33 \\
1.05 \\
0.88 \\
1.04 \\
0.30\end{array}$ & $\begin{array}{l}0.59 \\
0.39 \\
0.55 \\
0.45 \\
0.53 \\
0.39 \\
0.41 \\
0.47 \\
0.21\end{array}$ & $\begin{array}{l}1.29 \\
0.49 \\
1.03 \\
0.75 \\
0.92 \\
0.87 \\
0.61 \\
0.62 \\
0.14\end{array}$ & $\begin{array}{l}0.54 \\
0.22 \\
0.47 \\
0.36 \\
0.37 \\
0.36 \\
0.31 \\
0.34 \\
0.10\end{array}$ \\
\hline & $\begin{array}{l}\text { Mean } \\
\text { (all 9) }\end{array}$ & $1 \cdot 186$ & $0 \cdot 504$ & 0.853 & 0.379 & 0.537 & 0.289 & $0 \cdot 386$ & $0 \cdot 217$ & 0.998 & 0.443 & $0 \cdot 747$ & 0.341 \\
\hline \multirow[t]{2}{*}{$\begin{array}{l}\text { Control } \\
\text { normal }\end{array}$} & $\begin{array}{l}10 \\
11 \\
12 \\
13 \\
14 \\
15 \\
16 \\
17 \\
18\end{array}$ & $\begin{array}{l}2.25 \\
1.68 \\
1.15 \\
1.89 \\
1.70 \\
1.43 \\
1.78 \\
1.71 \\
1.39\end{array}$ & $\begin{array}{l}0.73 \\
0.68 \\
0.56 \\
0.60 \\
0.65 \\
0.55 \\
0.57 \\
0.63 \\
0.55\end{array}$ & $\begin{array}{l}1.42 \\
1.19 \\
0.74 \\
0.99 \\
0.60 \\
0.72 \\
1.05 \\
0.90 \\
0.52\end{array}$ & $\begin{array}{l}0.55 \\
0.53 \\
0.40 \\
0.44 \\
0.34 \\
0.40 \\
0.44 \\
0.38 \\
0.27\end{array}$ & $\begin{array}{l}0.78 \\
1.03 \\
0.61 \\
0.79 \\
1.13 \\
0.36 \\
0.53 \\
0.51 \\
0.61\end{array}$ & $\begin{array}{l}0.47 \\
0.53 \\
0.30 \\
0.34 \\
0.46 \\
0.20 \\
0.30 \\
0.28 \\
0.32\end{array}$ & $\begin{array}{l}0 \cdot 27 \\
0 \cdot 82 \\
0 \cdot 36 \\
0.52 \\
0 \cdot 30 \\
0 \cdot 22 \\
0.46 \\
0.35 \\
0 \cdot 19\end{array}$ & $\begin{array}{l}0 \cdot 18 \\
0 \cdot 46 \\
0 \cdot 23 \\
0 \cdot 33 \\
0 \cdot 18 \\
0 \cdot 15 \\
0 \cdot 29 \\
0 \cdot 20 \\
0 \cdot 12\end{array}$ & $\begin{array}{l}1.80 \\
1.41 \\
0.99 \\
1.40 \\
1.35 \\
0.95 \\
1.34 \\
1.12 \\
1.05\end{array}$ & $\begin{array}{l}0.65 \\
0.62 \\
0.49 \\
0.49 \\
0.54 \\
0.40 \\
0.48 \\
0.46 \\
0.45\end{array}$ & $\begin{array}{l}1.09 \\
1.07 \\
0.58 \\
0.78 \\
0.43 \\
0.53 \\
0.84 \\
0.61 \\
0.36\end{array}$ & \begin{tabular}{|l}
0.45 \\
0.50 \\
0.33 \\
0.39 \\
0.25 \\
0.30 \\
0.39 \\
0.29 \\
0.20
\end{tabular} \\
\hline & $\begin{array}{l}\text { Mean } \\
\text { (all 9) }\end{array}$ & $1 \cdot 664$ & 0.613 & 0.903 & 0.417 & 0.706 & 0.356 & $0 \cdot 388$ & $0 \cdot 238$ & $1 \cdot 268$ & 0.509 & 0.699 & $0 \cdot 344$ \\
\hline
\end{tabular}

used is the so-called Hotelling's $\mathrm{T}^{2}$ test. A visual clarification of the principle underlying this test is shown for $\bar{x} R_{1}$ and $\bar{x} R_{2}$ in the figure. The difference in phagocytosis between normal and pyridoxine-deficient animals was highly significant for each of the main cell-types and for all cells participating in phagocytosis if all four parameters were combined (row 7, table II).

Although $\bar{x}$ (the average number of ingested bacteria) and $\phi$ (the proportion of cells participating in phagocytosis) combined at $R_{1}$ and $\boldsymbol{R}_{2}$ (cell-tobacterium ratios of 0.44 and 0.66 ) showed a highly significant difference in phagocytosis between diet and control animals, discrimination involving all 
four parameters was difficult to interpret. It was, therefore, of interest to find a simple yet reasonably sensitive combination of parameters for the desired discrimination. The combination of $\bar{x} R_{1}$ and $\bar{x} R_{2}$ was found to be highly discriminatory whether the polymorphonuclear leucocytes alone or all phagocytic cells were used as indicator (row 5, columns 1 and 3 of table II, and the figure). The combination of $\phi R_{1}$ and $\phi R_{2}$ (row 6, table II) was less discriminatory. When the parameters were used individually, a significant difference in phagocytic activity between normal and pyridoxine-deficient animals was found only for $\bar{x} R_{1}$ if the polymorphonuclear leucocyte was used as indicator

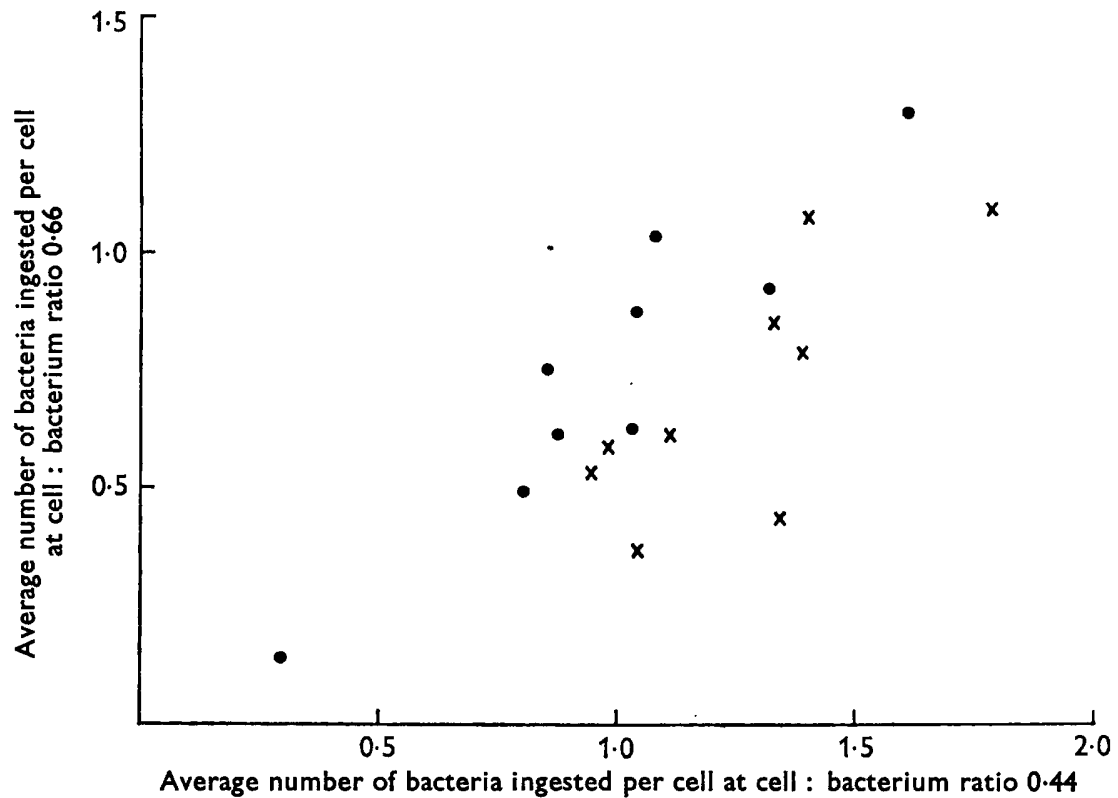

FIGURE.-Good discrimination in phagocytic activity between the diet group $(\bullet)$ and control group $(\times)$ achieved by plotting the average number of bacteria $(\bar{x})$ ingested by all cells participating in phagocytosis at $\mathrm{c} / \mathrm{b}$ ratio 0.66 against those at ratio 0.44 .

(row 1 , column 1 of table II). The average number of bacteria ingested appeared to be a more sensitive parameter than the proportion of cells participating in phagocytosis (rows 1 and 3 ; rows 5 and 6 of table II), and the polymorphonuclear leucocyte was a better indicator cell than the metamyelocyte (columns 1 and 2 of table II).

In the figure, the values of $\bar{x} R_{1}$ and $\bar{x} R_{2}$ for the diet and control animals are presented. It was apparent that the line separating the two groups of points is oblique, indicating that $\bar{x} R_{1}$ and $\bar{x} R_{2}$ combined is much more discriminatory than $\bar{x} R_{1}$ or $\bar{x} R_{2}$ separately. The slope of this separating line is very close to $45^{\circ}$, indicating that $\bar{x} R_{1}-\bar{x} R_{2}$ is approximately the best linear combination.

The differences in the proportion of cell-types over the four slides taken from individual animals (two at each $c / b$ ratio) were larger than could be expected on the basis of statistical fluctuations. The observed differences in 
$\bar{x}$ between the two slides at $R_{1}$ and $R_{2}$ slightly exceeded random fluctuation, whilst those of $\phi$ were well within this range. From table III, which gives a number of variance components, it may be concluded that sufficient observations have been made, since the variance within animals is appreciably smaller than the variance between animals.

TABLE II

Significance of various combinations of $\bar{x}$ and $\phi$ at cell-to-bacterium ratios of $0.44\left(\bar{x} R_{1}\right.$ and $\left.\phi R_{1}\right)$ and $0.66\left(\bar{x} R_{2}\right.$ and $\left.\phi R_{2}\right)$

\begin{tabular}{|c|c|c|c|}
\hline \multirow{2}{*}{ Parameter used } & \multicolumn{3}{|c|}{ Value of $P$ for the stated parameter for } \\
\hline & $\underset{\text { poucocytes }}{\text { polymorphonuclear }}$ & metamyelocytes & $\begin{array}{l}\text { all phagocytic } \\
\text { cells }\end{array}$ \\
\hline $\begin{array}{l}\bar{x}_{n} R_{1}-\bar{x}_{d} R_{1} * \dagger \\
\bar{x}_{n} R_{2}-\bar{x}_{d} R_{2} \\
\phi_{n} R_{1}-\phi_{d} R_{1} \\
\phi_{n} R_{2}-\phi_{d} R_{2} \\
\bar{x}_{n} R_{1}-\bar{x}_{d} R_{1}+\bar{x}_{n} R_{2}-\bar{x}_{d} R_{2} \\
\phi_{n} R_{1}-\phi_{d} R_{1}+\phi_{n} R_{2}-\phi_{d} R_{2} \\
\bar{x}_{n} R_{1}-\bar{x}_{d} R_{1}+\bar{x}_{n} R_{2}-\bar{x}_{d} R_{2}+\phi_{n} R_{1}-\phi_{d} R_{1} \\
\quad+\phi_{n} R_{2}-\phi_{d} R_{2}\end{array}$ & $\begin{array}{l}0.03 \\
0.8 \\
0.06 \\
0.5 \\
0.0005 \\
0.009 \\
<0.00005\end{array}$ & $\begin{array}{c}0.2 \\
1.0 \\
0.2 \\
0.7 \\
0.2 \\
0.2 \\
<0.00005\end{array}$ & $\begin{array}{l}0.07 \\
0.5 \\
0.1 \\
0.9 \\
0.01 \\
0.07 \\
<0.00005\end{array}$ \\
\hline
\end{tabular}
diet.

* Subscript $\boldsymbol{n}$ refers to animals on a normal diet, subscript $\boldsymbol{d}$ to those on a pyridoxine-deficient $\dagger$ Strictly speaking, each of the components of each difference is multiplied by a factor to give a discriminant function with minimal misclassification effect.

TABLE III

Estimates of variance of the average number of ingested bacteria $(\bar{x})$ and proportion of cells participating in phagocytosis $(\phi)$ for polymorphonuclear leucocytes

\begin{tabular}{l|c|c|c|c}
\hline \multirow{2}{*}{ Animals } & \multirow{2}{*}{ Parameter } & \multicolumn{3}{|c}{ Variance of the stated parameter } \\
\cline { 2 - 4 } & within slides & between slides & between animals \\
\hline Diet-deficient group & $\bar{x}$ & $\begin{array}{l}0.0118 \\
0.00095\end{array}$ & $\begin{array}{l}0.0190 \\
0.00005\end{array}$ & $\begin{array}{l}0.1958 \\
0.0168\end{array}$ \\
\hline Control group & $\bar{\phi}$ & $\begin{array}{l}0.0239 \\
0.0013\end{array}$ & $\begin{array}{l}0.0099 \\
0.0008\end{array}$ & $\begin{array}{l}0.0806 \\
0.0034\end{array}$ \\
\hline
\end{tabular}

In this experiment, and all other experiments under different test conditions, the distribution of bacteria in the cells deviated highly significantly from the Poisson distribution, the variance being generally higher than the average number of ingested bacteria.

\section{Discussion}

Deviation of the observed frequency distribution of bacteria in phagocytes from the Poisson distribution has several consequences. If the observed 
frequency distribution of bacteria in phagocytes had followed the Poisson distribution, the average number of ingested bacteria $(\bar{x})$ could have been calculated as $\{\bar{x}=-\ln (1-\phi)\}$ from the proportion of cells participating in phagocytosis $(\phi)$. The proportion of cells participating in phagocytosis is much less difficult and time-consuming to read, but the number of bacteria ingested and marked for destruction is of much greater interest. The differences of $\bar{x} R_{1}$ and of $\bar{x} R_{2}$ between diet-deficient and control animals can be interpreted in terms of load. With few bacteria, the activity of the phagocytic cells of the diet-deficient and control animals did not differ very much. With increased bacterial load, the cells of the deficient animals failed to meet the challenge, both in ingestion of bacteria and in the number of cells participating in phagocytosis. However, increased bacterial load allows better discrimination only up to a point. If the $\mathrm{c} / \mathrm{b}$ ratio is decreased much below 0.44 , reading of the slides becomes inaccurate because of the difficulty in judging the intraor extra-cellular position of the bacteria. The difference in phagocytic activity between the groups, although not very impressive, indicates that pyridoxine deficiency causes a lowered resistance through impairment of the ingestive capacity of phagocytes.

\section{SUMMARY}

We detected subtle differences between the phagocytic activity of cells from pyridoxine-deficient and normal guinea-pigs by means of a suitable combination of parameters at two different cell-to-bacterium ratios. This difference was modest in amount, but statistically highly significant. The best parameter for discrimination was the average number of ingested bacteria per cell and the best indicator cell was the polymorphonuclear leucocyte.

Increasing the load of bacteria increased the difference in phagocytic activity between pyridoxine-deficient and control animals. These results could be achieved only by increasing the accuracy of estimates of the cell-to-bacterium ratio ten-fold above those obtained by conventional counting methods, and by eliminating the variability due to conducting experiments on different days with different bacterial suspensions.

The valuable suggestions of Professor Dr K. C. Winkler are sincerely appreciated. The experimental design was suggested by Professor Dr G. Leppink and Dr M. Schulzer, who also provided the statistical analysis and the interpretation of the results. The technical assistance of Miss A. Quik is gratefully acknowledged.

\section{REFERENCES}

Cottingham, Esther, AND Mills, C. A. 1943. Influence of environmental temperature and vitamin-deficiency upon phagocytic functions. J. Immun., 47, 493.

IRINODA, K., AND MIKAMI, H. 1958. Angular blepharoconjunctivitis and pyridoxine (vitamin $\mathrm{B}_{6}$ ) deficiency. Archs Ophthal., N.Y., 60, 303.

Mitsui, Y., HINOKUMA, S., AND TANAKA, C. 1951. Etiology of angular conjunctivitis. Amer. J. Ophthal., 34, 1579. 